\title{
CCAAT/enhancer-binding protein $\alpha$ decreases the viability of gastric cancer cells
}

\author{
MINORU TOMIZAWA ${ }^{1}$, FUMINOBU SHINOZAKI ${ }^{2}$, YASUFUMI MOTOYOSHI ${ }^{3}$, \\ TAKAO SUGIYAMA $^{4}$, SHIGENORI YAMAMOTO ${ }^{5}$ and NAOKI ISHIGE ${ }^{6}$ \\ Departments of ${ }^{1}$ Gastroenterology, ${ }^{2}$ Radiology, ${ }^{3}$ Neurology, ${ }^{4}$ Rheumatology, ${ }^{5}$ Pediatrics and ${ }^{6}$ Neurosurgery, \\ National Hospital Organization, Shimoshizu Hospital, Yotsukaido, Chiba 284-0003, Japan
}

Received May 6, 2016; Accepted February 23, 2017

DOI: $10.3892 / 01.2017 .5987$

\begin{abstract}
CCAAT/enhancer-binding protein (C/EBP) $\alpha$, $\mathrm{C} / \mathrm{EBP} \beta$ and $\mathrm{C} / \mathrm{EBP} \delta$ are involved in inflammation and cell differentiation. In the present study, their roles in human gastric cancer cells were investigated. The human gastric cancer cell lines MKN45 and MKN74 were subjected to the reverse transcription-quantitative polymerase chain reaction (RT-qPCR) to analyze the expression levels of $\mathrm{C} / \mathrm{EBP} \alpha$, $\mathrm{C} / \mathrm{EBP} \beta$ and $\mathrm{C} / \mathrm{EBP} \delta$. The cells were transfected with expression plasmids for either $\mathrm{C} / \mathrm{EBP} \alpha$ or $\mathrm{C} / \mathrm{EBP} \delta$, and subjected to a 3-(4,5-dimethylthiazol-2-yl)-5-(3-carboxymethoxyphenyl)2-(4-sulfophenyl)-2H-tetrazolium inner salt (MTS) assay and RT-qPCR for analysis of cyclin D1 expression. Expression levels of $\mathrm{C} / \mathrm{EBP} \alpha$ and $\mathrm{C} / \mathrm{EBP} \delta$ were decreased in MKN45 and MKN74 cells compared with in normal gastric tissue. Expression levels of $\mathrm{C} / \mathrm{EBP} \beta$ were decreased in MKN45 cells and increased in MKN74 cells. Viability of MKN45 cells was decreased by $\mathrm{C} / \mathrm{EBP} \alpha$ and $\mathrm{C} / \mathrm{EBP}$. Viability of MKN74 cells was decreased by $\mathrm{C} / \mathrm{EBP} \alpha$, but increased by $\mathrm{C} / \mathrm{EBP} \delta$. Expression levels of cyclin D1 were decreased in association with $\mathrm{C} / \mathrm{EBP} \alpha$ and $\mathrm{C} / \mathrm{EBP} \delta$ overexpression in MKN45 cells. Expression levels of cyclin D1 were decreased in association with $\mathrm{C} / \mathrm{EBP} \alpha$ overexpression, but increased in association with $\mathrm{C} / \mathrm{EBP} \delta$ overexpression, in MKN74 cells. The results of the present study indicate that $\mathrm{C} / \mathrm{EBP} \alpha$ is potentially useful for the treatment of gastric cancer.
\end{abstract}

Correspondence to: Dr Minoru Tomizawa, Department of Gastroenterology, National Hospital Organization, Shimoshizu Hospital, 934-5 Shikawatashi, Yotsukaido, Chiba 284-0003, Japan E-mail: nihminor-cib@umin.ac.jp

Key words: gastric cancer, CCAAT/enhancer-binding protein $\alpha$, CCAAT/enhancer-binding protein $\beta$, CCAAT/enhancer-binding protein $\delta$, reverse transcription-quantitative polymerase chain reaction, 3-(4,5-dimethylthiazol-2-yl)-5-(3-carboxymethoxyphenyl)2-(4-sulfophenyl)-2 $\mathrm{H}$-tetrazolium inner salt assay, episomal vector

\section{Introduction}

Gastric cancer (GC) is a leading cause of cancer-related mortality globally (1). Prognosis is poor in patients with advanced GC (2). Endoscopic surgical resection is currently used for the treatment of early-stage GC only (3). The lack of non-surgical alternatives in treatment approaches has resulted in a requirement to develop novel and targeted therapies to treat GC.

CCAAT/enhancer-binding proteins (C/EBPs) are transcription factors that belong to the family of basic leucine zipper proteins, and regulate gene expression in cell viability and inflammation $(4,5) . \mathrm{C} / \mathrm{EBP} \alpha, \mathrm{C} / \mathrm{EBP} \beta$ and $\mathrm{C} / \mathrm{EBP} \delta$ are involved in terminal differentiation of cells and inflammatory processes (6-8). Furthermore, the expression levels of C/EBP $\alpha$ and $\mathrm{C} / \mathrm{EBP} \beta$ are altered in cancerous tissue compared with in surrounding healthy tissues (9). Although it has been demonstrated previously that C/EBPD is involved in GC (10), its specific role remains unknown. The specific roles of $\mathrm{C} / \mathrm{EBP} \alpha$, $\mathrm{C} / \mathrm{EBP} \beta$ and $\mathrm{C} / \mathrm{EBP} \delta$ in $\mathrm{GC}$ remain incompletely understood.

Therefore, the expression levels of $\mathrm{C} / \mathrm{EBP} \alpha, \mathrm{C} / \mathrm{EBP} \beta$ and $\mathrm{C} / \mathrm{EBP} \delta$ were investigated in $\mathrm{GC}$ cells as a potential treatment method to decrease the viability of GC cells. Experiments were conducted using the Epstein-Barr virus (EBV) episomal vector. EBV episomal vector containing the latent origin of replication, oriP, and nuclear antigen are able to efficiently transfect host cells, and stably express and amplify genes of interest in daughter cells following division (11).

\section{Materials and methods}

Cell culture. The GC cell lines MKN45 and MKN74 were purchased from RIKEN BioResource Center Cell Bank (Tsukuba, Japan). Cells were cultured in $10 \mathrm{~cm}$ dishes (Asahi Techno Glass Corporation, Funabashi, Japan) in RPMI-1640 medium (Sigma; Merck KGaA, Darmstadt, Germany) supplemented with $10 \%$ fetal bovine serum (FBS; Thermo Fisher Scientific, Inc., Waltham, MA, USA) at $37^{\circ} \mathrm{C}$, in a humidified chamber containing $5 \% \mathrm{CO}_{2}$.

Plasmid construction and transfection. A C/EBP $\alpha$ fragment, digested with $N r u$ I-EcoRV from pG28B5.0 plasmid (kindly provided by Dr Kleanthis G. Xanthopoulos, 
IRRAS AB, Stockholm, Sweden), was subcloned into EcoRV sites of the episomal vector pEBMulti-Neo (Wako Pure Chemical Industries, Ltd., Osaka, Japan) to generate $\mathrm{pEB} / \mathrm{C} / \mathrm{EBP} \alpha-\mathrm{Neo}(12)$. A C/EBPd fragment digested with EcoRI from IRCB003O22 (RIKEN BioResource Center DNA Bank, Tsukuba, Japan) was subcloned into pBluescript2SK(-) (Agilent Technologies, Inc., Santa Clara, CA, USA) to construct pBlue/C/EBPd. An EcoRV-BamHI-digested fragment of pBlue/C/EBPS was subcloned into the EcoRV-BamHI site of $\mathrm{pEBMulti-Neo}$ to generate $\mathrm{pEB} / \mathrm{C} / \mathrm{EBP} \delta-\mathrm{Neo}$. Episomal plasmid vector constructs were transfected into $\mathrm{GC}$ cells and normal gastric mucosa cells. $\mathrm{pEB} / \mathrm{C} / \mathrm{EBP} \alpha-\mathrm{Neo}$ and $\mathrm{pEB} / \mathrm{C} / \mathrm{EBP} \delta$-Neo were transfected using Lipofectamine ${ }^{\circledR}$ LTX (Thermo Fisher Scientific, Inc.) into the cell cultures at concentrations of 10 or $100 \mathrm{ng} /$ well in 96-well plates and at $2 \mu \mathrm{g} /$ well in 6-well plates, according to the manufacturer's protocol. Mock transfection was carried out without nucleic acid material.

Cell viability analysis. Cells were trypsinized, harvested, centrifuged at $100 \times \mathrm{g}$ for $3 \mathrm{~min}$ at $4^{\circ} \mathrm{C}$ and seeded in 96-well flat-bottom plates (Asahi Techno Glass Corporation) at a density of 1,000 cells/well, and incubated for $24 \mathrm{~h}$ in Dulbecco's modified Eagle's medium (Sigma; Merck KGaA) supplemented with $10 \%$ FBS. Following incubation for $24 \mathrm{~h}$, the cells were transfected with $\mathrm{pEB} / \mathrm{C} / \mathrm{EBP} \alpha-\mathrm{Neo}$ or $\mathrm{pEB} / \mathrm{C} / \mathrm{EBP} \delta-\mathrm{Neo}$. Following incubation for $72 \mathrm{~h}$, cell viability was analyzed using a 3-(4,5-dimethylthiazol-2-yl)-5-(3-carboxymethoxy phenyl)-2-(4-sulfophenyl)-2H-tetrazolium inner salt (MTS) assay (Promega Corporation, Madison, WI, USA), according to the manufacturer's protocol. MTS is bioreduced by viable cells into a colored formazan product with an absorbance at $490 \mathrm{~nm}$. Absorbance at $490 \mathrm{~nm}$ was analyzed using an iMark Microplate Absorbance Reader (Bio-Rad Laboratories, Inc., Hercules, CA, USA). Mock-transfected cells were used as a control.

Reverse transcription-quantitative polymerase chain reaction (RT-qPCR). GC and normal gastric mucosa cells were cultured in 6-well plates (Asahi Techno Glass Corporation). When the cells reached $70 \%$ confluence, they were transfected with 0 , $0.25,0.75$ or $2.5 \mathrm{mg} \mathrm{pEB} / \mathrm{C} / \mathrm{EBP} \alpha-\mathrm{Neo}$ or $\mathrm{pEB} / \mathrm{C} / \mathrm{EBP} \delta-\mathrm{Neo}$. Total RNA was isolated using Isogen (Nippon Gene Co., Ltd., Tokyo, Japan) and $5 \mu \mathrm{g}$ RNA was used for first-strand cDNA synthesis, using the SuperScript III First-Strand Synthesis system (Thermo Fisher Scientific, Inc.), according to the manufacturer's protocol. qPCR was performed using Fast SYBR Green Master Mix (Thermo Fisher Scientific, Inc.) for 40 cycles with $5 \mathrm{sec}$ of denaturation at $95^{\circ} \mathrm{C}$ and $5 \mathrm{sec}$ of annealing/extension at $60^{\circ} \mathrm{C}$. PCR primers and amplicon lengths for qPCR are presented in Table I. Ribosomal protein L19 (RPL19), a constitutively expressed housekeeping gene (13), was used as an endogenous control to monitor the amount of mRNA. The gene expression levels were automatically analyzed using the MiniOpticon system (Bio-Rad Laboratories, Inc.), based on the $\Delta \Delta \mathrm{Cq}$ method (14). The relative expression levels were calculated as the expression level of a specific gene divided by that of RPL19. Human whole stomach RNA was purchased from Clontech Laboratories, Inc. (Mountain View, CA, USA) and used as a healthy control.

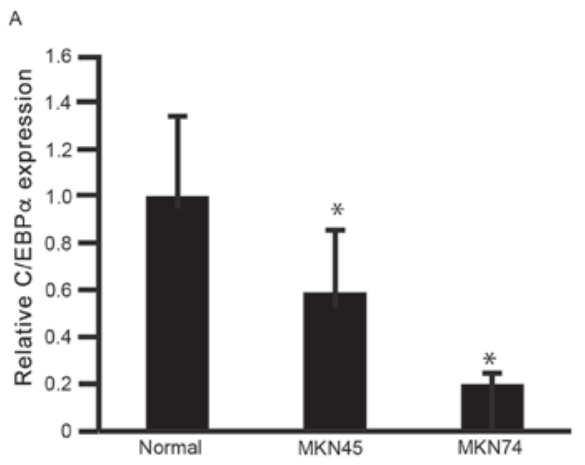

B

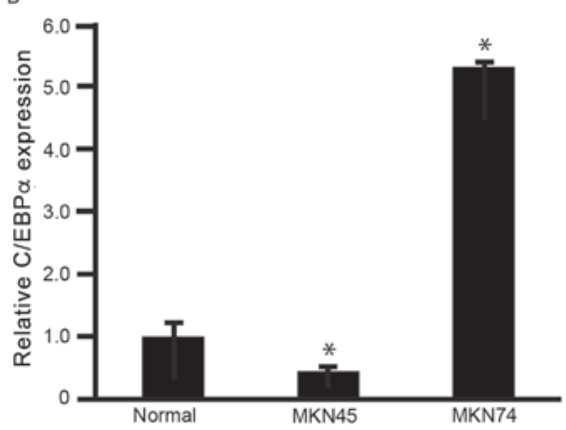

C

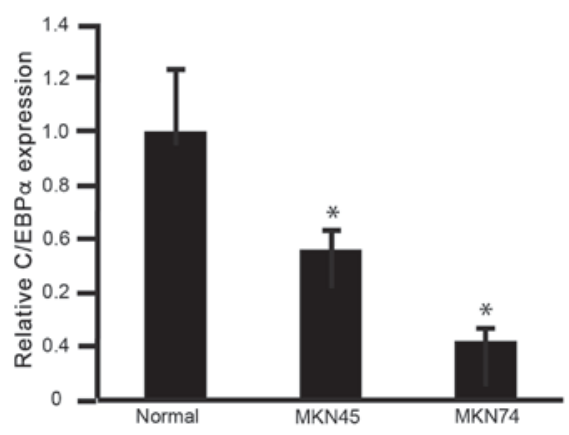

Figure 1. Expression levels of C/EBP mRNAs in gastric cancer cells. Total RNA was isolated from human gastric cancer MKN45 and MKN74 cells, and subjected to the reverse transcription-quantitative polymerase chain reaction to analyze the mRNA expression levels of (A) $\mathrm{C} / \mathrm{EBP} \alpha$, (B) $\mathrm{C} / \mathrm{EBP} \beta$ and $(\mathrm{C}) \mathrm{C} / \mathrm{EBP} \delta$ in gastric cancer cells compared with those of normal gastric mucosa (normal). ${ }^{*} \mathrm{P}<0.05$ vs. normal cells $(\mathrm{n}=3)$. C/EBP, CCAAT/enhancer-binding protein.

Statistical analysis. One-way analysis of variance was calculated using JMP software (version 10.0.2; SAS Institute, Cary, $\mathrm{NC}$, USA) to evaluate statistical significance. $\mathrm{P}<0.05$ was considered to indicate a statistically significant difference.

\section{Results}

To determine the expression levels of $\mathrm{C} / \mathrm{EBP} \alpha$ (Fig. 1A), $\mathrm{C} / \mathrm{EBP} \beta$ (Fig. 1B) and C/EBPd (Fig. 1C) in GC cells, RNA was isolated from MKN45 and MKN74 cells for analysis using RT-qPCR. The expression levels of $\mathrm{C} / \mathrm{EBP} \alpha$ and $\mathrm{C} / \mathrm{EBP} \delta$ were significantly decreased in MKN45 and MKN74 cells, compared with normal stomach (gastric) mucosa $(\mathrm{P}<0.05$; Fig. 1A and $\mathrm{C}$ ). The expression levels of $\mathrm{C} / \mathrm{EBP} \beta$ were significantly decreased in MKN45 cells, but significantly increased in MKN74 cells, compared with normal stomach mucosa $(\mathrm{P}<0.05$; Fig. 1B). These results indicated that $\mathrm{C} / \mathrm{EBP} \alpha$ and $\mathrm{C} / \mathrm{EBP} \delta$ warranted further investigation for their potential 
Table I. Primer sequences and conditions for the quantitative polymerase chain reaction.

\begin{tabular}{|c|c|c|c|c|}
\hline $\begin{array}{l}\text { Primer } \\
\text { name }\end{array}$ & Sequence & Description & $\begin{array}{l}\text { Product } \\
\text { size, } \mathrm{kb}\end{array}$ & $\begin{array}{c}\text { GenBank }^{\circledR} \\
\text { accession no. }\end{array}$ \\
\hline OMC321 & 5'-CGAATGCCAGAGAAGGTCAC-3' & RPL19, forward & 157 & ВC095445 \\
\hline OMC322 & 5'-CCATGAGAATCCGCTTGTTT-3' & RPL19, reverse & & \\
\hline OMC351 & 5'-CGGACTTGGTGCGTCTAAGATG-3' & $\mathrm{C} / \mathrm{EBP} \alpha$, forward & 148 & U34070 \\
\hline OMC352 & 5'-GCATTGGAGCGGTGAGTTTG-3' & $\mathrm{C} / \mathrm{EBP} \alpha$, reverse & & \\
\hline OMC355 & 5'-AGAGGCGGAGGAGAACAAACAG-3' & Cyclin D1, forward & 180 & NM_053056 \\
\hline OMC356 & 5'-AGGCGGTAGTAGGACAGGAAGTTG-3' & Cyclin D1, reverse & & \\
\hline OMC569 & 5'-AAGCACAGCGACGAGTACAA-3' & $\mathrm{C} / \mathrm{EBP} \beta$, forward & 155 & BC007538 \\
\hline OMC570 & 5'-AGCTGCTCCACCTTCTTCTG-3' & $\mathrm{C} / \mathrm{EBP} \beta$, reverse & & \\
\hline OMC571 & 5'-AGAAGTTGGTGGAGCTGTCG-3' & $\mathrm{C} / \mathrm{EBP}$, forward & 101 & BC105109 \\
\hline OMC572 & 5'-CAGCTGCTTGAAGAACTGCC-3' & $\mathrm{C} / \mathrm{EBP}$, reverse & & \\
\hline
\end{tabular}

RPL19, ribosomal protein L19, C/EBP; CCAAT/enhancer binding protein.

A

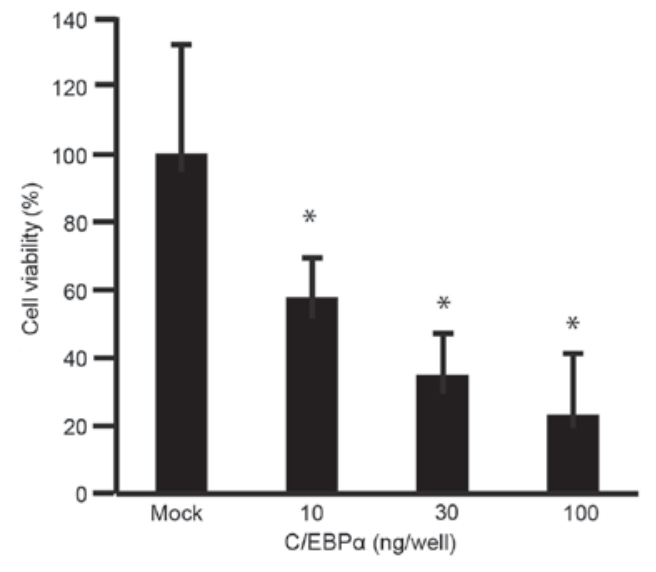

C

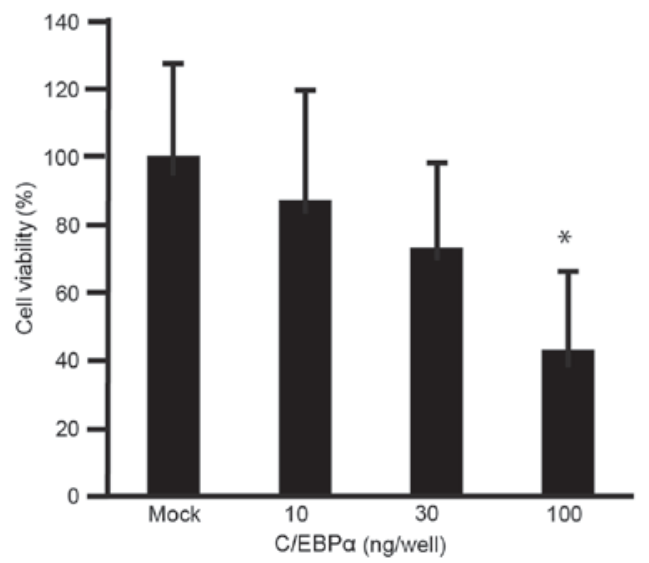

B
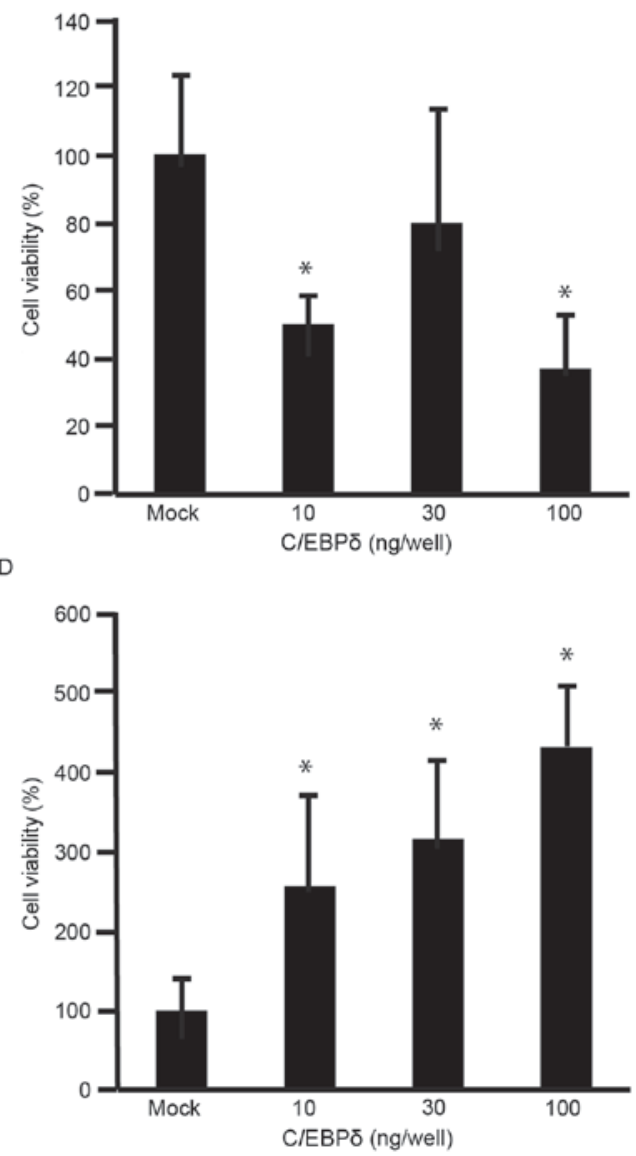

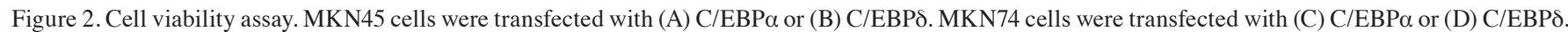
Transfection without nucleic acid material was used as a mock control. At $72 \mathrm{~h}$ after transfection, cells were subjected to a cell viability assay. Results are expressed relative to the mock control. ${ }^{*} \mathrm{P}<0.05$ vs. mock-transfected cells $(\mathrm{n}=3)$. C/EBP, CCAAT/enhancer-binding protein.

involvement in decreasing GC cell viability. However, the biological significance of $\mathrm{C} / \mathrm{EBP} \beta$ in $\mathrm{GC}$ cells was not clear from these results.

The viability of MKN45 cells was decreased by $\mathrm{C} / \mathrm{EBP} \alpha$ (Fig. 2A) and C/EBPS (Fig. 2B), compared with that of mock-transfected cells $(\mathrm{P}<0.05)$. Although the viability of MKN74 cells was significantly decreased by $\mathrm{C} / \mathrm{EBP} \alpha$ at 100 ng/well ( $\mathrm{P}<0.05$; Fig. 2C), it was significantly increased by $\mathrm{C} / \mathrm{EBP} \delta(\mathrm{P}<0.05$; Fig. $2 \mathrm{D})$. These results indicated that $\mathrm{C} / \mathrm{EBP} \alpha$ decreased the viability of GC cells. To further 

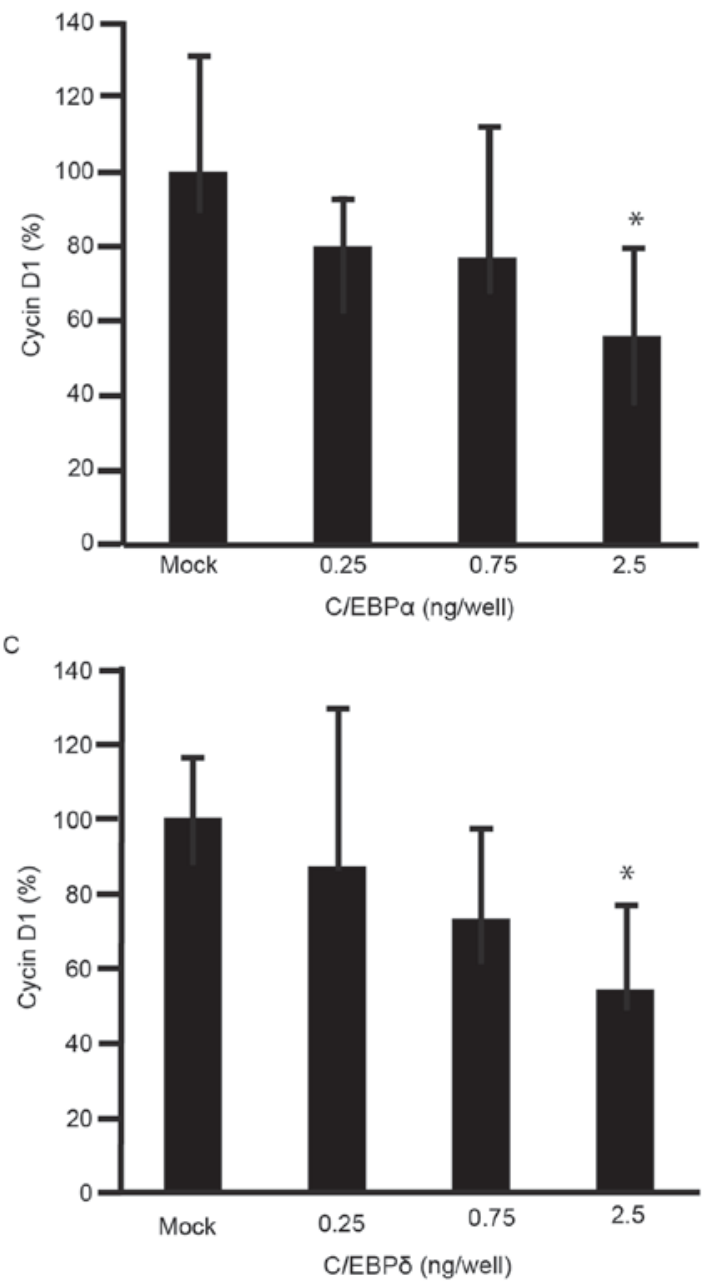
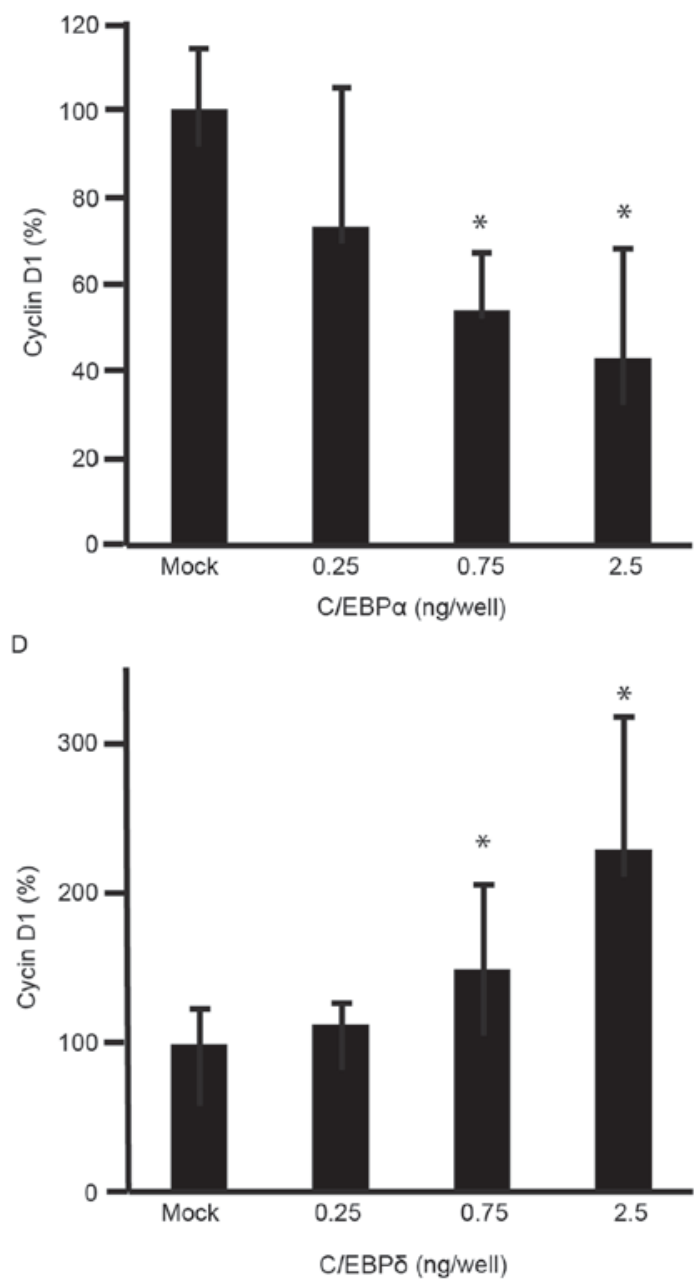

Figure 3. RT-qPCR analysis of cyclin D1 mRNA expression. (A) MKN45 cells or (B) MKN74 cells were transfected with C/EBP $\alpha$, and subjected to RT-qPCR of cyclin D1. (C) MKN45 cells or (D) MKN74 cells (D) were transfected with C/EBPd, and subjected to RT-qPCR of cyclin D1. Transfection without nucleic acid material was used as a mock control. Results are expressed relative to the mock control. * $\mathrm{P}<0.05$ vs. mock-transfected cells ( $\mathrm{n}=3$ ). RT-qPCR, reverse transcription-quantitative polymerase chain reaction; C/EBP, CCAAT/enhancer-binding protein.

understand the effects of $\mathrm{C} / \mathrm{EBP} \alpha$ and $\mathrm{C} / \mathrm{EBP} \delta$ on cell viability, expression levels of cyclin D1 were analyzed using RT-qPCR. The expression levels of cyclin D1 were decreased in MKN45 and MKN74 cells transfected with $\mathrm{C} / \mathrm{EBP} \alpha$ (Fig. 3A and B). The expression levels of cyclin D1 were decreased in MKN45 cells transfected with $\mathrm{C} / \mathrm{EBP} \delta$ (Fig. 3C), but increased in MKN74 cells transfected with C/EBPd (Fig. 3D).

\section{Discussion}

$\mathrm{C} / \mathrm{EBP} \alpha$ is expressed in normal gastric epithelium and downregulated in GC (15). Previous studies have also demonstrated that $\mathrm{C} / \mathrm{EBP} \alpha$ decreased the viability of hepatocellular carcinoma cells $(16,17)$. In the present study, the expression levels of $\mathrm{C} / \mathrm{EBP} \alpha$ were identified to be decreased in GC cells. The results indicated that $\mathrm{C} / \mathrm{EBP} \alpha$ is able to facilitate tumor cell suppression in GC. $\mathrm{C} / \mathrm{EBP} \alpha$ was able to decrease metastasis of GC by upregulating microRNA-100 (18). The results of the present study indicated that expressing $\mathrm{C} / \mathrm{EBP} \alpha$ is potentially useful in the targeted treatment of GC.
Previous studies have demonstrated that, during inflammation, $\mathrm{C} / \mathrm{EBP} \delta$ is recruited to the promoter region of cyclooxygenase-2, although its expression levels remained constant (19). Currently, to the best of our knowledge, no conclusive study of the expression levels of C/EBPD in GC cells has been performed. In liver cancer, $\mathrm{C} / \mathrm{EBP} \delta$ acts as a tumor suppressor (20). In the present study, C/EBPS was downregulated in $\mathrm{GC}$ cells, indicating that $\mathrm{C} / \mathrm{EBP} \delta$ acted as a tumor suppressor. However, $\mathrm{C} / \mathrm{EBP} \delta$ decreased the viability of MKN45 cells, but increased the viability of MKN74 cells. These results indicated that C/EBPS may serve an ambiguous role as a tumor suppressor or promoter, but it was not possible to determine this conclusively. Further studies may assist in our understanding of the functional role of C/EBPS in GC. In the present study, the expression levels of $\mathrm{C} / \mathrm{EBP} \beta$ were decreased in MKN45 cells. It was assumed that not all GC cells exhibited increased expression of $\mathrm{C} / \mathrm{EBP} \beta$; however, it was not possible to determine the percentage of GC cells that did. The expression level of $\mathrm{C} / \mathrm{EBP} \beta$ in $\mathrm{GC}$ is generally increased compared with that in healthy gastric epithelium (21). In further studies, immunohistological and flow cytometric analysis of cell cycle 
should be performed to improve our understanding of the expression of $\mathrm{C} / \mathrm{EBP} \alpha, \mathrm{C} / \mathrm{EBP} \beta$ and $\mathrm{C} / \mathrm{EBP} \delta$.

The expression levels of $\mathrm{C} / \mathrm{EBP} \alpha$ and $\mathrm{C} / \mathrm{EBP} \delta$ were decreased in $\mathrm{GC}$ cells compared with in healthy gastric epithelium. Expression of $\mathrm{C} / \mathrm{EBP} \alpha$ decreased the viability of GC cells, and, therefore, $\mathrm{C} / \mathrm{EBP} \alpha$ may potentially be used in novel GC therapies.

\section{Acknowledgements}

The present study was supported by a Grant-in-Aid for Scientific Research (C) from the Japan Society for the Promotion of Science (grant no. 15K09032).

\section{References}

1. Jemal A, Bray F, Center MM, Ferlay J, Ward E and Forman D: Global cancer statistics. CA Cancer J Clin 61: 69-90, 2011.

2. De Vita F, Di Martino N, Fabozzi A, Laterza MM, Ventriglia J, Savastano B, Petrillo A, Gambardella V, Sforza V, Marano L, et al: Clinical management of advanced gastric cancer: The role of new molecular drugs. World J Gastroenterol 20: 14537-14558, 2014.

3. Kim MY, Cho JH and Cho JY: Ever-changing endoscopic treatment for early gastric cancer: Yesterday-today-tomorrow. World J Gastroenterol 20: 13273-13283, 2014.

4. Tsukada J, Yoshida Y, Kominato Y and Auron PE: The CCAAT/enhancer (C/EBP) family of basic-leucine zipper (bZIP) transcription factors is a multifaceted highly-regulated system for gene regulation. Cytokine 54: 6-19, 2011.

5. Kheolamai P and Dickson AJ: Liver-enriched transcription factors are critical for the expression of hepatocyte marker genes in mES-derived hepatocyte-lineage cells. BMC Mol Biol 10: 35, 2009.

6. Tomizawa M, Garfield S, Factor V and Xanthopoulos KG: Hepatocytes deficient in CCAAT/enhancer binding protein alpha (C/EBP alpha) exhibit both hepatocyte and biliary epithelial cell character. Biochem Biophys Res Commun 249: 1-5, 1998.

7. Yamasaki H, Sada A, Iwata T, Niwa T, Tomizawa M, Xanthopoulos KG, Koike T and Shiojiri N: Suppression of C/EBPalpha expression in periportal hepatoblasts may stimulate biliary cell differentiation through increased Hnf6 and Hnflb expression. Development 133: 4233-4243, 2006.

8. Akira S, Isshiki H, Sugita T, Tanabe O, Kinoshita S, Nishio Y, Nakajima T, Hirano T and Kishimoto T: A nuclear factor for IL-6 expression (NF-IL6) is a member of a C/EBP family. EMBO J 9: 1897-1906, 1990.

9. Tomizawa M, Horie H, Yamamoto H, Matsunaga T, Sasaki F, Hashizume K, Hiyama E, Kaneko M, Suita S, Ando H, et al: Reciprocal expression of CCAAT/enhancer binding proteins $\alpha$ and $\beta$ in hepatoblastomas and its prognostic significance. Oncol Rep 17: 341-344, 2007.
10. Balamurugan $\mathrm{K}$ and Sterneck E: The many faces of C/EBPd and their relevance for inflammation and cancer. Int J Biol Sci 9: 917-933, 2013.

11. Yates JL, Warren N and Sugden B: Stable replication of plasmids derived from Epstein-Barr virus in various mammalian cells. Nature 313: 812-815, 1985.

12. Antonson $\mathrm{P}$ and Xanthopoulos KG: Molecular cloning, sequence, and expression patterns of the human gene encoding CCAAT/enhancer binding protein alpha (C/EBP alpha). Biochem Biophys Res Commun 215: 106-113, 1995.

13. Davies B and Fried M: The L19 ribosomal protein gene (RPL19): Gene organization, chromosomal mapping, and novel promoter region. Genomics 25: 372-380, 1995.

14. Tam S, Clavijo A, Engelhard EK and Thurmond MC: Fluorescence-based multiplex real-time RT-PCR arrays for the detection and serotype determination of foot-and-mouth disease virus. J Virol Methods 161: 183-191, 2009.

15. Regalo G, Resende C, Wen X, Gomes B, Durães C, Seruca R, Carneiro F and Machado JC: C/EBP alpha expression is associated with homeostasis of the gastric epithelium and with gastric carcinogenesis. Lab Invest 90: 1132-1139, 2010.

16. Tomizawa M, Wang YQ, Ebara M, Saisho H, Watanabe K, Nakagawara A and Tagawa M: Decreased expression of the CCAAT/enhancer binding protein $\alpha$ gene involved in hepatocyte proliferation in human hepatocellular carcinomas. Int J Mol Med 9: 597-600, 2002.

17. Tomizawa M, Watanabe K, Saisho H, Nakagawara A and Tagawa M: Down-regulated expression of the CCAAT/enhancer binding protein alpha and beta genes in human hepatocellular carcinoma: A possible prognostic marker. Anticancer Res 23: 351-354, 2003.

18. Shi DB, Wang YW, Xing AY, Gao JW, Zhang H, Guo XY and Gao P: C/EBP $\alpha$-induced miR-100 expression suppresses tumor metastasis and growth by targeting ZBTB7A in gastric cancer. Cancer Lett 369: 376-385, 2015.

19. Chen JJ, Huang WC and Chen CC: Transcriptional regulation of cyclooxygenase- 2 in response to proteasome inhibitors involves reactive oxygen species-mediated signaling pathway and recruitment of CCAAT/enhancer-binding protein delta and CREB-binding protein. Mol Biol Cell 16: 5579-5591, 2005.

20. Li CF, Tsai HH, Ko CY, Pan YC, Yen CJ, Lai HY, Yuh CH, Wu WC and Wang JM: HMDB and 5-AzadC combination reverses tumor suppressor CCAAT/enhancer-binding protein delta to strengthen the death of liver cancer cells. Mol Cancer Ther 14: 2623-2633, 2015.

21. Regalo G, Canedo P, Suriano G, Resende C, Campos ML, Oliveira MJ, Figueiredo C, Rodrigues-Pereira P, Blin N, Seruca R, et al: C/EBPbeta is over-expressed in gastric carcinogenesis and is associated with COX-2 expression. J Pathol 210: 398-404, 2006 